\title{
○大頭実保子・松浦健次郎・小池靖夫（徳島大学耳鼻咽喉科）
}

難聴児のスクリーニング法として, 聴性行動反応を観察する方法と, 難聴に関するリス

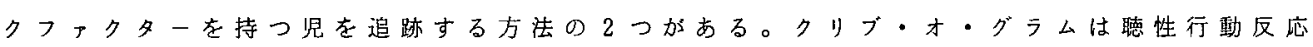
を自動的・客観的にとらえようという方法であるが，リスクファクターに基く選別法との 比較はまだ充分に行なわれていない。前回のオージオロジー学会において，われわれは， リスクフォクターとクリブオグラム判定との関係をф係数を用いて検討した。今回は数量 化理論を用いて，とれらの関係について検討した成績を報告する。

<対象及び方法 $>$

德島大学附属病院産婦人科にて出生した新生児 502 名にうき胎生週数; 出生体重等を記 録し，全員にクリブオグラム榆査を行った。検査の結果，REFER（要精検）となった児に は，さらに再検査を行い, :2回ともREFERとなった児にはABRを行っだ。検查を行った 児のその後の聴覚反応につき,アンケート調查を行った。

次に,クリブオグラム検查を行った新生児のうち, 詳細な病歴を記録し得た 350 名につ いて，表 1 に示すようなリスクファクタ一の有無を検討した。

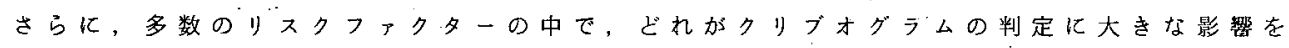
与えているかを知るため，数捂化理論II類を用いて検討を行った。計算にはマイクロコン ピュータE P S O N Q C 10 を使用した。

$<$ 結果 $>$

502 名の新生児のうち,クリブオグラムで，REFERの判定を受けたのは，57名であった。 表 2 に示すように, リスクフォクタ一の有無を調查できた 350 名のうち, スクファクタ 一を持たないlow risk 児は274名, リスクファクターを持つhigh risk児は76名で，あった。 low risk児のうち, PASS となったのは257名, REFERとなったのは17名であった。 high risk児のうち, PASSとなったのは4 47 名, REFERとなったのは29名であった。 high risk览の 持つリスクファクタ一の内訳を表了に示した。リスクファクターの内, 頻度が多いのは, 高ビリルビン血症, 低出生体重であり, 次いで, 異常神経学微侯, 胎児切迏仮死が, 他の リスクフナクターより,やや多い傾向を示した。

リスクフナクターのそれぞれを説明変数（Item）として採用し，各リスクフナクタ一を 持つか否かをCategoryとし，クリブオグラム判定を目的变数として，数量化理論II類によ り，各ItemのCategory Scoreを計算した。計算の結果，胎児切迫仮死，呼吸障害，奇北の 3つのリスクファクターが,クリブオグラムのREFER判定をむたらすために大きな影残を あつ事が明らかになった。

\section{$\langle$ 考察>}

前前回のオージオロジー学会で,リスクファクターの中には頻度が多いが, REFERとなる 事とは密接な関連を持たないものがあり，逆に頻度は少ないが，REFERとなる承と密接な 関連を持つものがある事を指摘した。REFERとなる事に大きな影帮を持つリスクファクタ 一は, 
結果は, ф係数による解析結果とは僅加に異っている。との差は，2つの統計方法の迹い を示するのと思われる。

新生児の聴覚スクリーニング法として多数の方法が提案されているか，どの方法加，む つとも有効加というコンセンサスは得られていない。リスクファクターのみのスクリー = ングではリスクを持たない難聴児を検出できず,クリブォグラムでは；体動の情報のみか ら判定を行っているから，難聴がくであ体動の少ない児を检出する事になる。両者の欠 点を補いつつ, 難聴児の検出率をあげる試み加望ましい。また, 難聴飞関するリスクフフ クターのどれが，他のファクターより重要であるかという相対的評価はまだされていない。 各々のリスクファクタ一の重要性の程度を数量化し, 難聴児検出の精度を高めていく事加 重要亡思われる。

\section{RISK FACTORS}

1. positive family history of deafness

2. respiratory disturbance

3. anomaly

4. Low birth weight (less than 2500g)

5. Low Apgar score (less than 6 after 5 minutes)

6. fetal distress

7. hyperbilirubinemia (more than $15 \mathrm{mg} / \mathrm{d} 1$ )

8. suspected intrauterine infection

9. neurological abnormal findings (e.g. tetany, cyanosis, etc.)

$\begin{array}{lrcr} & \text { PASS } & \text { REFER } & \text { total } \\ \text { low risk } & 257 & 17 & 274 \\ \text { high risk } & 47 & 29 & 76 \\ \text { total } & 304 & 46 & 350 \\ & & & \end{array}$

表 1

表 2

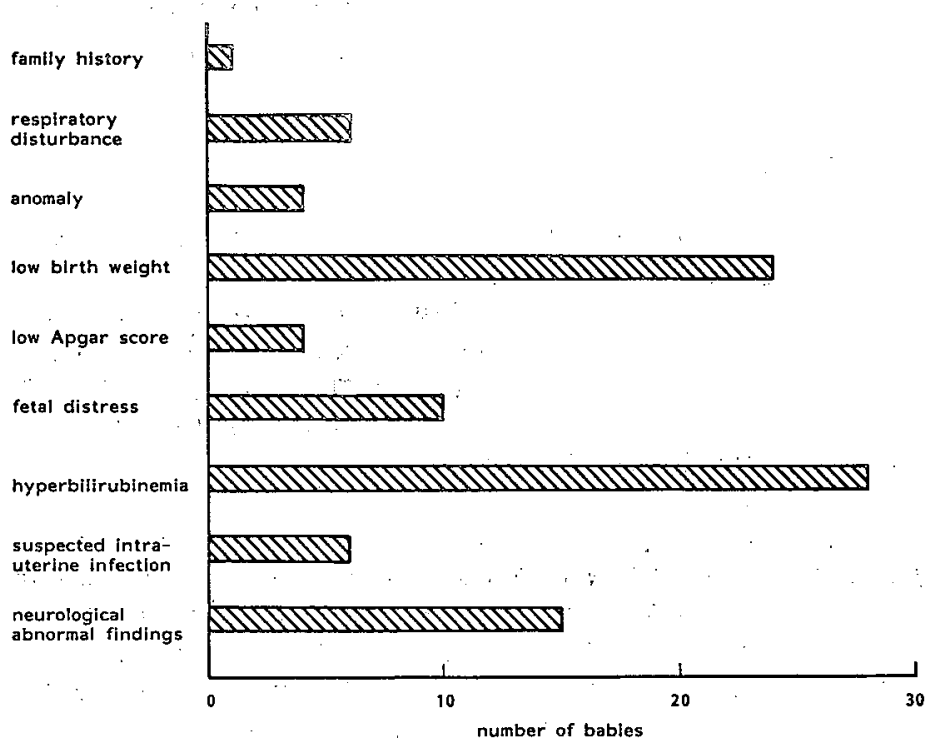

表 3 